\title{
Phytochemical, Proximate and Elemental Composition of Tithonia diversifolia (Hemsley) A. Gray leaves
}

\author{
Omolola, T.O \\ Forestry Research Institute of Nigeria \\ * Corresponding author email: oyebee710@gmail.com \\ Received: 09 June 2019 / Revised: 12 August 2019 / Accepted: 19 August 2019 / Published: 30 August 2019
}

\begin{abstract}
In recent times, medicinal plants are being greatly used ethnomedicinally for the management and treatment of diseases and health conditions. One of such medicinal plants is Tithonia diversifolia. This study aimed at determining the phytochemical, elemental and proximate content of the powdered plant part to help infer what is responsible for the reported therapeutic characteristics of the plant as well as determine the quality, purity and safety profile of the plant. Leaves of T.diversifolia were subjected to phytochemical, proximate and mineral screening using standard laboratory procedures. Qualitative phytochemical observation revealed the presence of Tannins, saponins, flavonoids and terpenoids. Crude Protein content was the highest with $27.69 \%$ followed by Crude Fibre (14.89\%), Ash (13.86\%), Moisture Content (10.92\%) and the least value 1.14\% for Fat. Magnesium (Mg) content was highest with $6712.50 \mathrm{mg} / \mathrm{kg}$ which is $22,35,122 \& 144$ times higher than the content of Iron (Fe) $(291.5 \mathrm{mg} / \mathrm{kg})$, Manganese $(\mathrm{Mn})(191.0 \mathrm{mg} / \mathrm{kg})$, Zinc $(\mathrm{Zn})(54.9 \mathrm{mg} / \mathrm{kg})$ and Copper $(\mathrm{Cu})(15.1 \mathrm{mg} / \mathrm{kg})$. However, elements (heavy metals) Lead (Pb), Cadmium (Cd), Chromium (Cr) and Cobalt (Co) were not detected. Results obtained in the study is indicative of a potential drug substitute which can be used to help manage and treat diseases due to the phytochemicals, nutrients, and minerals present in them. Also, the safety indices of this plant part have been established, thus, information obtained from the study can serve as a reference standard for the plant monograph.
\end{abstract}

Keywords: Tithonia diversifolia, Phytochemicals, Minerals, Heavy metals, Proximate

\section{Introduction}

Tithonia diversifolia (Hemsley) A. Gray is a representative of the sunflower family (Asteraceae) and it is popularly called Tree Marigold, Mexican Sunflower, Japanese Sunflower [1]. It is a perennial or annual shrub that is native to North and Central America, but is naturalised in Africa, Australia, and Asia, where it is an aggressively invasive species [2]. It is a prolific weed, which grows aggressively abandoned farmland, along road paths all over Nigeria. Due to the invasive nature of this plant in Nigeria, farmers have abandoned their lands as a result of the challenges experienced in ensuring the Mexican sunflower does not take over their farms [2],[3]. Despite its invasive nature, the plant has been used as an organic fertiliser to increase the yield of vegetable crops and maize in Nigeria and Kenya [2]. It is a woody herb/succulent shrub usually $1.2-3 \mathrm{~m}$ tall. The leaves are simple, alternately arranged, lobed with acute or acuminate apex, crenate margins. 5-17 X 3.5$12 \mathrm{~cm}$ in size, densely pubescent beneath with palmate venation. Flower heads are solitary on a peduncle $6-13 \mathrm{~cm}$ in length; florets yellow [2], [4], [5]. The plant is an important medicinal plant whose leaf is the major plant part used alone or in combination with other plants for the treatment of a variety of ailments such as stomach pain, indigestion, sore throat, liver disease and pain [1],[4]. Traditionally, all parts of the plant especially the leaves, are widely used by indigenous people for treating a wide spectrum 
of ailments and diseases ranging from topical application - to treat wounds, skeleto-muscular disorders, abscesses, dermatological conditions, and stomach pains - to oral administration for diabetes, malaria, fever, hepatitis and infectious diseases [6]. In Indonesia, the decoction of the aqueous extract of the plant is used for the treatment of diarrhoea, diabetes, stomach ache and wounds [2], [7]. In Nigeria, the leaf is used for managing and treating malaria [6]. Leaf infusion in water is taken orally to cure menstrual pain [2], [8]. Oral administration of cold water leaf infusion is used to treat malaria. It is applied topically as poultice or bath to wounds, bruises, skeletomuscular disorders, abscesses, dermatological conditions, and stomach pains [1]. Reported pharmacological activities include antiplasmodial [1], Antiinflammatory, antidiabetic [9], antioxidant [10], [11], [12], antibacterial [1], [13], antidiarrheal [1], acute toxicity [1], antimalarial [1], [14], hepatoprotective [1], anticancer, antiulcer, toxicology and cytotoxicity [1]. Phytochemical detected from the leaves includes phenolics, flavonoids, saponins, alkaloids, steroids, and tannins [15].

Qualitative and quantitative determination of mineral elements present in plants is important because they play a crucial role against a variety of degenerative diseases. It is also important to note that some minerals are essential to a healthy diet (e.g. Magnesium Calcium, Phosphorus, Potassium and Sodium) while some can be toxic (e.g. Lead, Mercury, Cadmium and Aluminium). Thus, the knowledge of the elemental content of plants is needed because it may influence their active constituents' production and their pharmacological action. Active constituents of medicinal plants are metabolic products of plant cells and a number of trace elements are responsible for this metabolism [16].

Proximate evaluation provides valuable information on the nutritional content as well as accessing the quality of the sample such as moisture content, ash, fat, crude fibre, crude protein, etc. Ash is the remaining inorganic residue after water and organic matter have been removed from any sample by heating, which provides a measure of total amount of minerals within the sample. Minerals are not destroyed by heating and they have a low volatility as compared to other food components. Ashes give us an idea of the mineral matter contained in a plant. Thus, measuring it is important, because mineral matter may be the cause of a pharmacological effect [17].

The present investigation on the leaves of $T$. diversifolia was taken up with the aim of establishing certain botanical and chemical standards which could help in Crude drug identification, check adulteration and contribute to the existing monograph information as contained in herbal pharmacopoeias.

\section{Materials and Method}

\subsection{Plant collection and authentication}

The fresh leaves of T.diversifolia was collected in November, 2011, within the Staff school, University of Ibadan. The plant was authenticated by Mr Chukwuma, E.C in the Forest Herbarium, Institute (FHI) of Forestry Research Institute of Nigeria (FRIN), Ibadan, where voucher specimens were deposited. The plant was assigned a voucher specimen number FHI 109598.

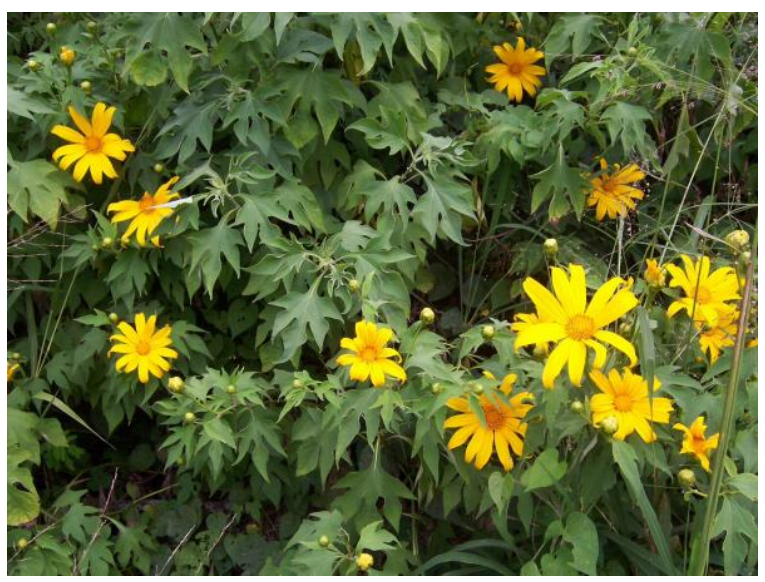

Figure 1: T. diversifolia growing in its natural habitat

\subsection{Voucher Specimen Preparation}

The plant part with inflorescence, fruits or seeds was collected and pressed using a plant press. They were then authenticated at FRIN by a taxonomist, further pressed to remove all the moisture, poisoned and mounted on a white cardboard paper making use of bond and paper tacks. The voucher number, province, district, 
locality, habitat, description of plant, collector, date and determinavit were documented on the herbarium specimens before depositing a copy at FHI.

\subsection{Phytochemical Screening}

\subsubsection{Test for Saponins}

About $1 \mathrm{~g}$ of the powdered sample was boiled in $5 \mathrm{ml}$ of distilled water in a water bath and filtered. $5 \mathrm{ml}$ of the filtrate was mixed with $5 \mathrm{ml}$ of distilled water and shaken vigorously for a stable persistent froth. The persistent frothing was taken as the evidence for the presence of saponins [18].

\subsubsection{Test for Tannins}

About $2 \mathrm{~g}$ of the dried powdered samples was boiled in $10 \mathrm{ml}$ of water in a test tube and then filtered. 2-5 few drops of $0.1 \%$ ferric chloride solution was added. The occurrence of a blueblack, green or blue-green precipitate indicates the presence of tannins [18].

\subsubsection{Test for Anthraquinones}

$2 \mathrm{~g}$ of the plant sample was extracted with $5 \mathrm{ml}$ of chloroform, filtered and $5 \mathrm{ml}$ of $10 \%$ ammonia solution added to the filtrate. The mixture was shaken and the presence of a pink, red, or violet colour in the ammoniacal (lower) layer indicated the presence of free anthraquinones.

Combined anthraquinones were tested for by boiling $2.5 \mathrm{~g}$ of each extract with $2.5 \mathrm{ml}$ of benzene, the benzene layer separated and half its own volume of $10 \% \mathrm{NH}_{3}$ solution added. A pink, red or violet coloration in the ammonia lower phase indicated the presence of derivatives of anthraquinone [18].

\subsubsection{Test for Cardiac Glycosides (Keller- Killiani Test)}

$1 \mathrm{~g}$ of the plant sample was extracted with $10 \mathrm{ml}$ of $80 \%$ ethanol for 5 minutes on a water bath. The extract was filtered and equal volume of distilled water was added to it. A few drops of lead acetate solution were added, shaken and the precipitates were filtered off. The filtrate was extracted with three aliquots of chloroform. The chloroform extract was divided into two portions in evaporating dish and evaporated to dryness on a steam bath.

a. Keller-Killiani's Test: To the first portion, $3 \mathrm{ml}$ of ferric chloride reagent $(0.3 \mathrm{ml}$ of $10 \%$ $\mathrm{FeCl}_{3}$ in $50 \mathrm{ml}$ glacial acetic acid) was added in a clean test tube. This was then underlayed with $1 \mathrm{ml}$ of concentrated sulphuric acid. A brown ring obtained at the interface indicates the presence of a deoxy sugar characteristic of cardenolides. A violet ring appeared below the brown ring while in the acetic acid layer a greenish ring formed just above the brown ring and gradually spread throughout this layer [18].

b. Kedde test: The second portion of the residue was mixed with $1 \mathrm{ml}$ of a $2 \%$ solution of 3,5-dinitrobenzoic acid in ethanol and $1 \mathrm{ml}$ of a $5 \%$ aqueous $\mathrm{NaOH}$. An immediate violet colour indicated the presence of cardenolides in the extract, the colour fading gradually through reddish - brown to brownish - yellow with the precipitation of a whitish crystalline solid. This test indicates the presence of a lactone ring in the cardenolides [18].

\subsubsection{Test for Flavonoids}

Shinoda's test: $0.5 \mathrm{~g}$ of each of the powdered sample was extracted in ethanol by boiling in a water bath for $5 \mathrm{~min}$, filtered and cooled. To the filtrate was added four pieces of magnesium filings followed by few drops of concentrated hydrochloric acid. A pink or red colour indicates the presence of flavonoids.

Sodium bydroxide Test: $5 \mathrm{ml}$ of $10 \% \mathrm{NaOH}$ was added to an equal volume of the ethanolic extract. A yellow colouration indicates the presence of flavonoids [18].

\subsubsection{Test for Alkaloids}

About $1 \mathrm{~g}$ of the plant powder was extracted with $5 \mathrm{ml}$ of $1 \%$ aqueous hydrochloric acid on a water bath. The $\mathrm{pH}$ of the filtrate was adjusted to about 6. To about $0.5 \mathrm{ml}$ of the filtrate few drops of Mayer's reagent, Drageendorff's reagent, Wagner's reagent, 1\% Picric acid solution and 10\% Tannic solution were added. Turbidity or precipitation with either of these reagents was taken as evidence for the presence of alkaloids in the extract evaluated [18]. 
Omolola T.O., Int. Ann. Sci.; Vol. 8, Issue 1, pp: 54-61, 2020

\subsection{Proximate Analysis}

The proximate analysis of powdered plant materials was carried out using the AOAC methods (2005) in the laboratory of the Department of Human Nutrition, Faculty of Medicine, University of Ibadan. The powdered plant sample was analysed for proximate compositions: moisture content, crude protein, crude fat, ash, crude fibre and carbohydrate [19].

\subsection{Elemental analysis}

Elemental analysis was done according to the method of Isaac and Korber, [20]. Briefly, $0.5 \mathrm{~g}$ of the powdered sample was weighed into a $50 \mathrm{ml}$ beaker and $10 \mathrm{ml}$ of an acid mixture in the ratio 2:1 $\left(\mathrm{HNO}_{3}: \mathrm{HClO}_{4}\right)$ was added and allowed to undergo heating on a hot panel placed in a fume cupboard for about 30 minutes until a clear solution(digest) was obtained. The digest was allowed to cool and the volume adjusted to $20 \mathrm{ml}$, this was read on an atomic absorption spectrophotometer (Buck Scientific, model210/211 VLP) to determine the heavy metal composition of the sample. The elements were determined at various wavelengths viz.

$\mathrm{Zn}=213.9 \mathrm{~nm}, \mathrm{Fe}=248.3 \mathrm{~nm}, \mathrm{Cu}=324.8 \mathrm{~nm}$,

$\mathrm{Cr}=357.9 \mathrm{~nm}, \mathrm{Co}=324.8 \mathrm{~nm}, \mathrm{Mg}=285.2 \mathrm{~nm}$

$\mathrm{Mn}=279.5 \mathrm{~nm}, \mathrm{Ni}=341.5 \mathrm{~nm}, \mathrm{Cd}=228.9 \mathrm{~nm}$, $\mathrm{Pb}=283.3 \mathrm{~nm}$.

\subsection{Statistical analysis}

Data collected were expressed as mean \pm standard deviation of triplicate analysis.

\section{Results}

\subsection{Phytochemical Screening}

The result of phytochemical analysis is shown in Table 1.

Table 1: Phytochemical Constituents of T. diversifolia leaves

\begin{tabular}{|l|c|}
\hline Constituents & T.diversifolia \\
\hline Tannins & + \\
\hline Saponin & + \\
\hline Cardiac Glycosides & - \\
\hline Anthraquinones & - \\
\hline Alkaloids & - \\
\hline Flavonoids & + \\
\hline Terpenoids & + \\
\hline Steroids & - \\
\hline
\end{tabular}

*Positive +, Negative
The phytochemical screening carried out on the leaves of $T$. diversifolia showed that it contains Tannins, Saponins, Flavonoids, Terpenoids while Alkaloids, Cardiac glycosides, Anthraquinones and steroids were found absent. The presence of these secondary metabolites is indicative of its promising array of potential pharmacological activities.

\subsection{Proximate analysis}

The evaluation of the proximate and physicochemical content of the leaves is represented in Table 2. The results revealed a moisture content value of $10.92 \%$, crude protein (27.69\%), Crude fibre (14.89\%), Fat (1.14\%), Ash $(13.86 \%)$, acid insoluble ash $(2.78 \%)$, water soluble ash $(7.80 \%)$, alcohol soluble extractive $(4.54 \%)$ and water soluble extractive $(19.13 \%)$. These values helps us appreciate the proximate qualities of the understudied plant which is quite important to ascertain the quality and purity of any crude drug.

Table 2: Proximate analysis and Physico-chemical parameters of $T$. diversifolia leaves

\begin{tabular}{|l|c|}
\hline Parameters & T. diversifolia (\%) \\
\hline Moisture content & $10.92 \pm 0.05$ \\
\hline Crude Protein & $27.69 \pm 0.16$ \\
\hline Fat & $1.14 \pm 0.01$ \\
\hline Crude Fibre & $14.89 \pm 0.04$ \\
\hline Ash & $13.86 \pm 0.05$ \\
\hline Acid insoluble ash & $2.78 \pm 0.25$ \\
\hline $\begin{array}{l}\text { Water soluble ash } \\
\text { Alcohol soluble } \\
\text { extractive }\end{array}$ & $4.80 \pm 1.58 \pm 0.65$ \\
\hline $\begin{array}{l}\text { Water } \\
\text { extractive }\end{array}$ & $19.13 \pm 0.15$ \\
*Values expressed as Mean \pm SD
\end{tabular}

\subsection{Elemental analysis}

The result obtained for the elemental study of T.diversifolia leaves is as shown in Table 3. Results revealed a very high content of $6712.50 \mathrm{mg} / \mathrm{kg}$ for Magnesium ( $\mathrm{Mg}$ ), The content of $\mathrm{Mg}$ is 22, 35, 122 \& 144 times higher than the content of $\mathrm{Fe} \quad(291.5 \mathrm{mg} / \mathrm{kg}), \quad \mathrm{Mn} \quad(191.0 \mathrm{mg} / \mathrm{kg}), \quad \mathrm{Zn}$ $(54.9 \mathrm{mg} / \mathrm{kg})$ and $\mathrm{Cu}(15.1 \mathrm{mg} / \mathrm{kg})$ while heavy metals $\mathrm{Co}, \mathrm{Cr}, \mathrm{Cd}, \mathrm{Pb}$, and $\mathrm{Ni}$ were not detected (ND). This result implies that T.diversifolia leaves have a better potential in making up for the 
deficiencies of some of these elements in human body when ingested and also connotes that the plant part is highly of great potential medicinally.

Table 3: Elemental analysis of T. diversifolia leaves

\begin{tabular}{|l|c|}
\hline Element & T. diversifolia (mg/kg) \\
\hline Magnesium $(\mathrm{Mg})$ & 6712.50 \\
\hline Manganese $(\mathrm{Mn})$ & 191.00 \\
\hline Iron $(\mathrm{Fe})$ & 291.50 \\
\hline Copper $(\mathrm{Cu})$ & 15.10 \\
\hline Zinc $(\mathrm{Zn})$ & 54.90 \\
\hline Cobalt $(\mathrm{Co})$ & ND \\
\hline Chromium $(\mathrm{Cr})$ & ND \\
\hline Cadmium $(\mathrm{Cd})$ & ND \\
\hline Lead $(\mathrm{Pb})$ & ND \\
\hline Nickel & ND \\
*ND - NOT DETECTED &
\end{tabular}

\section{Discussion}

Herbal medicines have received greater attention as alternatives to drug therapy, thus, leading to increase in their demand. The exclusive use of herbal drugs, prepared and dispensed by unscientifically trained herbalists, for treatment of diseases is still very common in rural Nigerian communities. Experimental screening method is, therefore, important in order to ascertain the safety and efficacy of herbal products as well as to establish the active components of these herbal remedies [21].

From the result of the phytochemical screening as represented in Table 1 . The finding is in accordance with the report of Taziebou et al [22]. In contrast, Ezeonwumelu et al [23] and Olayinka et al [24] reported the presence of Alkaloids.

Proximate analysis results as shown in Table 2 revealed that the ash value of $T$. diversifolia leaves is $13.86 \%$, this value is similar to the reported value of $14 \%$ [25] but higher than $8.10 \%$ as reported by Olayinka et al [24] which falls in the acceptable range of $22 \%$ for any standard drug [26]. Also, the value obtained was higher than the values of $6.55 \%$ and $11 \%$ obtained for $T$. diversifolia stem and leaves respectively [27]. Higher ash denotes higher mineral content, thus, we can say the plant sample understudied has a higher inorganic content than the samples used for the reported ones. Total ash value is a diagnostic index for purity. It represents the physiological ash and non-physiological ash. Physiological ash is the ash inherent in the plant due to biochemical processes and the nonphysiological ash is due to contaminants from the environment. These may be carbonates, phosphates, nitrates, sulphates, chlorides and silicates of various metals which were taken up from the soil [28]. The non-physiological ash component of the total ash could be reduced by rinsing the fresh plant material several times in clean water before drying and processing for medicinal uses. The acid-insoluble ash value measures the amount of silica, especially siliceous earth, present in the crude plant [28]. The acid insoluble ash was $2.78 \%$ while the water soluble ash was $7.80 \%$ are within the range reported for some official vegetable drugs like Cajanus seed (not more than $0.15 \%$ ), Capsicum fruits (not more than 1.5\%), Euphorbia whole herb (3\%) and Atropa leaf (5\%) [28]. The value obtained for water soluble ash indicates that about $7.80 \%$ of the total ash of T.diversifolia will be physiologically available when the plant drug is ingested.

The moisture content of $T$. diversifolia leaves is $10.97 \%$ as obtained in the study which is similar to the value of $10.00 \%$ recorded for T.diversifolia leaves by [29] and higher than the value of $9.27 \%$ obtained by [24]. Moisture content value obtained in this study is within the acceptable limits of about 6 to $15 \%$ for most vegetable drugs [28]. The importance of low moisture content is that it reduces errors in the estimation of the actual weight of drug material, reduces components hydrolysis by reducing the activities of hydrolytic enzymes which may destroy the active components, and also reduces the proliferation of microbial colonies and therefore minimize the chance of spoilage due to microbial attack. Excessive moisture in a given sample encourages microbial growth or contamination [30], therefore we can say the understudied sample has limited chances of microbial invasion. The determination of the crude protein content of any sample is important because of their nutritive values and because protein has been proven to be of paramount importance for the survival of man [31]. T. diversifolia leaves shows a high Crude protein content of $27.89 \%$ which indicates that it can be a very good source of 
protein. This value is almost double the value of $10.30 \%$ obtained by [29]. Proteins help improve the immune system and plays a major role in cell division and growth [32].

The study revealed Crude fibre content of $14.89 \%$ which is slightly higher than the value of $13.47 \%$ obtained for T. diversifolia leaves [24] and very much higher than $5.80 \%$ which was obtained by [29]. Fibres function by reducing the rate at which glucose is being absorbed into the blood stream thus reducing chances of having hyperglycemia [32]. Also, it is important to note that high fibre content of foods help in digestion and prevention of colon cancer [33]. This therefore implies that T.diversifolia has a potential to replace existing drugs used for the treatment of indigestion and colon cancer.

Fat composition was $1.14 \%$ which is quite low and is lower than the content of $2.47 \%$ reported by [24]. Fats are necessary for insulation and protection of vital organs as well as for hormone production [34]. The water-soluble extractive and alcohol soluble extractive gave $19.13 \%$ and $4.54 \%$ respectively The result for water and alcohol soluble extractive indicates that the amount of phytoconstituent is more in water than in alcohol. Extractive values are useful to evaluate the chemical constituents in the crude drug, as well as to determine their solubility in a particular solvent (water or alcohol). The values obtained shows that water will be a better solvent for extraction of $T$. diversifolia than alcohol

Elemental analysis (Table 3) revealed that $T$. diversifolia contains a high content of Magnesium $(\mathrm{Mg})(6712.5 \mathrm{mg} / \mathrm{kg})$. The content of $\mathrm{Mg}$ is 22, 35, 122 \& 144 times higher than the content of $\mathrm{Fe}$ (291.5mg/kg), Mn (191.0mg/kg), Zn $(54.9 \mathrm{mg} / \mathrm{kg})$ and $\mathrm{Cu}(15.1 \mathrm{mg} / \mathrm{kg})$. This value of $\mathrm{Mg}$ is three (3) times higher than that that of Cnicus benedictus (1764.64ppm) [16], a member of Asteraceae family. The high content of $\mathrm{Mg}$ is very significant because $\mathrm{Mg}$ is an important mineral involved in various metabolic reactions [35] and it is necessary for major biological processes, for example, the synthesis of nucleic acids and proteins and it also plays a very important role in many physiological functions [36]. $\mathrm{Mn}$ and $\mathrm{Fe}$ content of T. diversifolia leaves, $191.00 \mathrm{mg} / \mathrm{g}$ and $291.5 \mathrm{mg} / \mathrm{g}$ falls within the same range with the values $187.7 \mathrm{mg} / \mathrm{g}$ and $261.2 \mathrm{mg} / \mathrm{g}$ obtained for Chromolaena odorata, also a member of Asteraceae family while $\mathrm{Cu}$ and $\mathrm{Zn}$ content, $(148.3 \mathrm{mg} / \mathrm{g}$; $95.0 \mathrm{mg} / \mathrm{g})$ of $C$. odorata is much higher than that of T. diversifolia $(15.10 \mathrm{mg} / \mathrm{g} ; 54.90 \mathrm{mg} / \mathrm{g}$ ) [37]. $\mathrm{Zn}$ is an important mineral with antioxidant properties while $\mathrm{Cu}$ plays a major role in the utilization of $\mathrm{Fe}$ and mineralization of bones cortices. In $\mathrm{Fe}$ deficiency states known as anaemia, T.diversifolia leaves could be prescribed to ameliorate this condition [37]. Thus, we can infer that T.diversifolia can be used to treat and manage health conditions that set in due to the deficiency of some of these elements. However, elements (heavy metals) such as $\mathrm{Ni}, \mathrm{Co}, \mathrm{Cr}, \mathrm{Cd}$ (toxic), $\mathrm{Pb}$ (toxic) were not detected in the plant. Reports suggest that there is a close relationship between cases of declining reproductive health and environmental pollutants like lead [38].

Also, it has been documented that metals such as lead, cadmium, arsenic and mercury can affect male reproductive functions including sperm motility and morphology [39] and spermatogenesis [40]. Thus, the absence or nondetection of these toxic heavy metals in this plant part further corroborates the safety of the plant.

\section{Conclusion}

In view of the increasing interest and demand for the use of medicinal plants for health management, there is the rising compulsory need for the standardization of these medicinal plants and this present study has helped to create these standards. This study has highlighted the phytochemical, proximate and elemental nature of T.diversifolia leaves. The presence of plant secondary metabolites such as tannins, flavonoids, saponins is indicative of its pharmacological potential since the presence of a particular secondary metabolite in any plant directly influences the therapeutic ability of the plant. Also, the proximate and elemental composition has helped to ascertain the safety, quality and purity profile of the understudied plant which are all quality indices necessary to achieve standardization. Thus, we can conveniently say that T.diversifolia leaves has a great potential for the management and treatment of diseases and information about the 
plant has been documented therefore, it can serve as a substitute for the existing standard drugs used for the management and treatment of these diseases and health conditions. Worthy of note is the non-detection of toxic heavy metals in the understudied plant which has helped to further guarantee its safety. Also, this study has played a major contributory role in providing some of the plant information necessary for the development of monographs in herbal pharmacopoeias thereby serving as reference for future use. Since this study has reiterated the diverse potential of this plant as well as clearly highlighted its quality, it is therefore imperative for further studies such as in vitro and in vivo pharmacological assays to be carried out on the plant to help corroborate its specific activities.

\section{Competing Interests}

The author declared that no conflict of interest exists in this publication.

\section{How to Cite this Article:}

T. Omolola, "Phytochemical, Proximate and Elemental Composition of Tithonia diversifolia (Hemsley) A. Gray leaves”, Int. Ann. Sci., vol. 8, no. 1, pp. 54-61, Aug. 2019. doi: 10.21467/ias.8.1.54-61

\section{References}

[1]. L.Kawini, M. Bora, S.N. Upadhyay, J. Hazra. "Pharmacological Profile of Tithonia diversifolia (Hemsl.) A. Gray: A Comprehensive Review". Journal of Drug Research in Ayurvedic Sciences", vol. 2, no. 3, pp. 183-187, 2017.

[2]. A.A. Ajao and A.N. Moteetee. "Tithonia diversifolia (Hemsl.) A. Gray. (Asteraceae: Heliantheae), an invasive plant of significant ethnopharmacological importance: A review", South African Journal of Botany, vol. 113, pp. 396-403, 2017.

[3]. K.S. Chukwuka, S. Ogunyemi, and I. Fawole. "Ecological distribution of Tithonia diversifolia (Hemsl). A. Gray - a new exotic weed in Nigeria". Journal of Biological Science, vol. 7, pp. 709-719, 2007.

[4]. C. Orwa, A. Mutua, R. Kindt, R. Jamnadass, A. Simons. Agroforestry Database: A Tree Reference and Selection Guide Version 4.0. 2009

[5]. J. Kadungu, P. Anjarwalla, L. Mwaura, D.A. Ofon, R. Jamnadass, P.C.Stevenson, P. Smith. Pesticidal Plant Leaflet. World Agroforestry Centre, Nairobi, Kenya; ISBN: 978-92-9059-347-348. 2018.

[6]. A.M Tagne, F.Marino and M. Cosentino. "Tithonia diversifolia (Hemsl.) A. Gray as a medicinal plant: a comprehensive review of its ethnopharmacology, phytochemistry, pharmacotoxicology and clinical relevance", Journal of Ethnopharmacology, Volume 220, 28, Pages 94-116, June 2018.
[7]. M.S.H.Wahyuningsih, A.W. Mahardika, B. Arief, and H. Muhammad. "Isolation and identification of potential cytotoxic compound from Kembang bulan (Tithonia diversifolia (Hemsl.) A Gray) leaves". International Journal of Pharmaceutical Pharmacy Science, vol. 7, pp. 298-301, 2015.

[8]. V.B. Owoyele, C.O. Wuraola, A.O. Soladoy, and S.B. Olaleye. "Studies on the anti-inflammatory and analgesic properties of Tithonia diversifolia leaf extract". Journal of Ethnopharmacology, vol. 90, pp. 317-321, 2004.

[9]. J.O. Olukunle, A.O. Sogebi, and J.A. Oyewusi, J.A. "Anti-inflammatory and analgesic potential of aqueous leaf extract of Tithonia diversifolia in rodents". Journal of Natural Sciences Engineering and Technology. Vol. 13, pp. 82-90, 2014.

[10]. T.P. Mayara, D.B. Deisiane, D.S.P. Christopher, B.L.R. Alex, D.R. Ryan, D.P. Flavia, S.F.S. Paula, P.L.T. Núbia, and S.M.D.A. Sheylla. "Antioxidant effect of plant extracts of the leaves of Tithonia diversifolia (Hemsl.) A. Gray on the free radical DPPH". Journal of Chemical and Pharmaceutical Research", vol. 8, pp. 1182-1189, 2016

[11]. P. Hiransai, J. Tangpong, C. Kumbuar, N. Hoonheang, O. Rodpech, P. Sangsuk, U. Kajklangdon, and W. Inkaow. "Anti-nitric oxide production, anti-proliferation and antioxidant effects of the aqueous extract from Tithonia diversifolia". Asian Pacific Journal of Tropical Biomedicine, vol. 6, pp. 950-956, 2016.

[12]. K.D.P. Pulido, A.J.C. Dulcey, and J.H.I. Martinez. "New caffeic acid derivative from Tithonia diversifolia (Hemsl.) A. Gray butanolic extract and its antioxidant activity". Food Chemistry Toxicology, Volume 109, Part 2, Pages 1079-1085, November 2017.

[13]. O.O. Agboola, O. Stephen, J.O. Olowooyo, A.A. Ajao, and O. Aregbesola. "Chemical composition and antimicrobial activities of essential oil extracted from Tithonia diversifolia (Asteraceae) flower". Journal of Bioresources and Bioproducts vol. 1, pp. 169-176, 2016.

[14]. I.O. Oyewole, C.A. Ibidapo, D.O. Moronkola, A.O. Oduola, G.O. Adeoye, G.N. Anyasor, and J.A. Obansa. "Anti-malarial and repellent activities of Tithonia diversifolia (Hemsl.) leaf extracts". Journal of Medicinal Plant Research,vol. 2, pp. 171-175, 2008.

[15]. O.B. Umar, R.D. Alex, E.E. Obukohwo. "Phytochemical and proximate composition of Tithonia diversifolia (Hemsl.) A. Gray". Annals. Food Science and Technology, vol.16, pp. 195-200, 2015.

[16]. M. Zafar; M.A. Khan; M. Ahmad; G. Jan; S. Sultana; K. Ullah; S.K. Marwat; F. Ahmad; A. Jabeen; A. Nazir; A.M. Abbasi; Z. Rehman; Z. Ullah. "Elemental Analysis of Some Medicinal Plants Used in Traditional Medicine by Atomic Absorption Spectrophotometer (AAS)". Journal of Medicinal Plants Research. vol 4, no. 19, pp. 1987-1990, 2010.

[17]. N.D. Lethika, S.K. Santosh, A. Arun, M. Deepak. "A Comparative study on Proximate Analysis conducted on Medicinal Plants of Chhattisgarh, CG'. India Research Journal of Chemical Sciences, vol. 2, no. 9, pp. 18-21, 2012

[18]. G.E. Trease, W.C. Evans. Pharmacognosy. $15^{\text {th }}$ edition. Saunders publishers. 2002.

[19]. AOAC. "Official Methods of Analysis. 18 $8^{\text {th }}$ Edition". Association of Official Analytical Chemists, Washington, DC., USA. 2005. 
[20]. A.R. Isaac, J.D. Korber. "Atomic absorption and flame photometry Technique and uses in soil, plant and water analysis". In L.M. Walsh (Ed) Instrumental Methods for analysis of soils, and plant tissues. Soil Science Society America Incorporation Wisconsin USA.1971

[21]. R. Mythilypriya, P. Shanthi, P. Sachdanandam. "Oral acute and subacute toxicity studies with Kalpaamruthaa, a modified indigenous preparation, on rats". Journal of Health Science, vol. 53, no 4, pp. 351-358, 2007.

[22]. L.C. Taziebou, F.X. Etoa, B. Nkegoum, C.A. Pieme, D.P. Dzeufiet. "Acute and Subacute toxicity of Aspilia africana leaves". African. Journal of Traditional, Complementary and Alternative Medicines. Vol. 4, no. 2, pp. $127-134,2007$.

[23]. J.O.C. Ezeonwumelu, R.G. Omolo, A.M. Ajayi, E. Agwu, J.K. Tanayen, C.P. Adiukwu, A.A. Oyewale, B. Adzu, A.G. Okoruwa, S.O. Ogbonnia. "Studies of Phytochemical Screening, Acute Toxicity and AntiDiarrhoeal Effect of Aqueous Extract of Kenyan Tithonia diversifolia Leaves in Rats". British Journal of Pharmacology and Toxicology. vol 3, no. 3, pp. 127-134, 2012.

[24]. U.B. Olayinka, R.D. Alax, E.C. Obukowo. "Phytochemical and Proximate Composition of Tithonia diversifolia (Hemsl.) A.Gray". Annals. Food Science and Technology. vol.16, no. 1, pp. 195-200, 2015.

[25]. A.O. Fasuyi, F.A.S. Dairo, F.J. Ibitayo, F.J. "Ensiling wild sunflower (Tithonia diversifolia) leaves with sugar cane molasses". Livestock Research for Rural Development. vol. 22, no. 3, 2010.

[26]. British Pharmacopoeia. Can Med Assoc J. vol. 126, no.5, pp.514-515, 1980

[27]. U.A.Essiet, E.M. Akpan.. "Proximate Composition and Phytochemical Constituents of Aspilia Africana (Pers) C.D Adams and Tithonia diversifolia (Hemsl) A.Gray Stems (Asteraceae). 2013.

[28]. Kunle, O.F. 2000. "Phytochemical and microbiological studies of the leaf of Lippia mutiflora Mold. (Verbenaceae)". Phytomedicine, vol. 10, pp. 59-61

[29]. U.A. Essiet, N. Uriah. "Comparative Phytochemical and Physicochemical Properties of Aspilia Africana and Tithonia diversifolia leaves". International Journal of Modern Biology and Medicine, vol. 3, no. 3, pp. 113-122, 2013.

[30]. R. Guisseppe and T.M. Baratta. "Antioxidant activity of selected essential oil components in two lipid model systems". African Journal of Biotechnology. Vol. 69, no. 2, pp.167-174, 2000.

[31]. D.J. Voet, J.G. Voet, C.W. Pratt. "The Principles of Biochemistry". $3^{\text {rd }}$ Edition. John Wiley \& Sons, 111 River Street, Hoboken, pp. 74-219, 2008.

[32]. C.U. Okeke, C.N. Adaku. "Phytochemical and Proximate Analysis of Euphorbia heterophylla Linn. (Euphorbiaceae)". Nigerian Journal of Botany. Vol. 22, no.1, pp. 215-222, 2009.

[33]. UICC/WHO 2005. Global Action against Cancer NOW. Geneva: UICC and WHO Publications Department.

[34]. D. Dutta, U.R. Chaudhuri, and R. Chakraborty. "Structure, health benefits, antioxidant property and processing and storage of carotenoids". African Journal of Biotechnology, vol. 4, no. 13, pp. 1510 -1520, 2005.

[35]. J. Nishiura, A. Campus, M. Boim, N. Schor. "Effect of Phyllanthus niruri on urinary calcium levels in calcium stone forming patients". Journal of Clinical and
Laboratory Investigation of Urolothies and Related Areas. Vol. 32, no. 15, pp. 362-366, 2005.

[36]. A.C. de Oliverira, A.C. Perez, G. Merino, J.G. Prieto, A.I. Alvarez. "Protective effects of Panax ginseng on muscle injury and inflammation after eccentric exercise". Comparative Biochemistry and Physiology. Vol.130c, pp. 369-377, 2001.

[37]. E.I. Obiajunwa, A.C. Adebajo, O.R. Omobuwajo. "Essential and Trace Element contents of some Nigerian Medicinal Plants". Journal of Radioanalytical and Nuclear Chemistry. Vol 252, no. 3, pp. 473-476, 2012.

[38]. J.P. Bonde, P. Apostoli. "Any need to revisit the male reproductive toxicity of Lead?" Occupational and Environmental Medicine. Vol 62, no 1, pp 1-2, 2004.

[39]. J.D. Meeker, M.G. Rossano, B. Protas, M.P. Diamond, E. Pusheck, D. Daly, N. Paneth, J.J. Wirth. "Cadmium, Lead, and other metals in relation to semen quality: human evidence for molybdenum as a male reproductive toxicant". Environmental Health Perspective, vol. 116, no. 11, pp. 1473-1479, 2008

[40]. S. Telisman, B. Colak, A. Pizent, J. Jurasovic, P. Cvitkovic. "Reproductive Toxicity of low-level lead exposure in men". Environmental Research. vol.105, no. 2, pp. 255-266

\section{Publish your research article in AIJR journals- \\ $\checkmark \quad$ Online Submission and Tracking \\ $\checkmark \quad$ Peer-Reviewed \\ $\checkmark \quad$ Rapid decision \\ $\checkmark \quad$ Immediate Publication after acceptance \\ $\checkmark \quad$ Articles freely available online \\ $\checkmark \quad$ Retain full copyright of your article. \\ Submit your article at journals.aijr.in}

\section{Publish your books with AIJR publisher- \\ $\checkmark \quad$ Publish with ISBN and DOI. \\ $\checkmark \quad$ Publish Thesis/Dissertation as Monograph. \\ $\checkmark \quad$ Publish Book Monograph. \\ $\checkmark \quad$ Publish Edited Volume/ Book. \\ $\checkmark \quad$ Publish Conference Proceedings \\ $\checkmark \quad$ Retain full copyright of your books. \\ Submit your manuscript at books.aijr.org}

